\title{
Miracle Workers: Gender and State Mediation among Textile and Garment Workers in Mexico's Transition to Industrial Development
}

\author{
Jocelyn Olcott \\ Duke University
}

\begin{abstract}
In the 1930s, the Mexican federal government consolidated political control following the chaos of the revolution and developed strategies for industrial development and economic growth. In 1936, at the height of the Popular Front and amid unabashedly progressive declarations by Mexican President Lázaro Cárdenas, the Department of Labor ordered an investigation to insure the protection of women's and children's labor rights. The "new woman" in postrevolutionary Mexico would be both a conscientious mother (protected by her husband) and a productive wage laborer (protected by the paterfamilias of the federal government). Two years later, confronting political and economic realities within Mexico, the Cárdenas government all but abandoned this agenda, turning a blind eye to labor abuses as labor-intensive enterprises leaned on underpaid women workers to facilitate the transition to industrial production.
\end{abstract}

In July 1936, Mexico's Department of Labor released its first report by the Investigative Committee of the Situation of Women and Children Workers. ${ }^{1}$ Citing the desires of president Lázaro Cárdenas (1934-1940), the department head, Genaro Vázquez, had issued the committee a broad mandate to ascertain women's salaries across Mexico's diverse industries and regions and to examine the justifications for any gaps between men's and women's salaries and labor protections. Vázquez instructed the committee to report any workplace conditions that threatened women's security or health. He called on inspectors to consider the "social condition of woman ... since the Revolution should care for the feminine factor with the same attention that it has shown to date for the masculine factor." He also directed the committee to report on children's labor conditions, citing the "Department's preoccupation with continuing decisive support for the revolutionary program discouraging child factory labor." Despite the committee's ambitious goals, it concentrated its energies where it expected the most abject exploitation: Mexico City's garment industry.

Dividing the city into zones, the inspection committee's five educated, middle-class women pounded the pavement, tracking down every garmentmaking workshop they could. Their expectations were not disappointed. Labor law violations abounded and, according to the inspectors, the workers lacked the class-consciousness and economic security to challenge their employers. Given the postrevolutionary regime's emphasis on linking education with worker emancipation, inspectors wondered why a group of women with relatively high liter-

(c) 2003 International Labor and Working-Class History, Inc. 
acy and education levels would subject themselves to "the intolerable condition of industrial slavery." "Understanding "industrial slavery" as culturally rather than structurally rooted, they identified three principal explanations for this apparent paradox. The first, "of a hereditary character," held that women had grown accustomed to their submissive roles in the traditional Mexican household. Second, "the revolutionary ideology, and with it class consciousness, has not penetrated the proletarian households in the desirable proportion." Finally, this sector's low unionization levels impeded garment workers from agitating for their own emancipation, risking job loss and blacklisting.

The report exudes state paternalism, not only pointing to the responsibility of the "Revolution [to] care for the feminine factor" but also assuming that "class consciousness" would come from the leaders of the postrevolutionary regime and penetrate working-class households, rather than the reverse. Rhetorically, these reformers placed both women (the "feminine factor") and the working class ("proletarian households") outside of the "Revolution" itself.

The investigative committee's language highlights three publicly contested issues: industrial modernization, regime consolidation, and postrevolutionary gender ideologies. In all three realms, the Cárdenas government faced difficult choices. It sought industrialization but within a nationalist framework and without displacing the country's thousands of small producers. Likewise, it strove to consolidate a strong central government without alienating important investors and local political bosses and to update prevailing gender practices without upsetting time-honored patriarchal traditions. The Cardenista consensus-building project required careful navigation of these three areas to construct the infrastructure of state-orchestrated conflict mediation.

As the Cárdenas administration negotiated the complex political terrain among Communist-led Popular Front organizations, an increasingly militant suffrage movement, and the burgeoning fascist organizations, government agencies like the Labor Department shifted their emphasis from paternalist mobilization to social and political stability. After explaining the relationship among gender ideologies, labor politics, and postrevolutionary regime consolidation, this article examines the textile and garment industries during this crucial transition to the so-called Mexican Miracle, a period from the 1940s to 1960s characterized by rapid industrialization, economic development, and political stability. Juggling social, economic, and political priorities, policymakers struggled to balance support for women's rights as wage earners with the expectations of their unpaid domestic labor. By 1940, just as the "Miracle" began to take off, the regime had accommodated its more conservative critics, focusing its energies on supporting professional women and full-time mothers rather than wage earners.

\section{Gender, Labor Politics, and Regime Consolidation}

Less than three weeks before Genaro Vázquez ordered the investigation, Cárdenas described the state as the "arbiter and regulator of social life." 3 Several weeks later, Cárdenas informed an employers' organization in Mexico City that 
The modern concept of the State's function and the very nature of the labor legislation in its universal breadth require that cases of doubt be resolved to favor the weaker party. Granting equal treatment to two unequal parties is neither to impart justice nor to work with equity. ${ }^{4}$

This vision of the postrevolutionary state defining and mediating class relations conspicuously characterized the Cárdenas government as it vacillated between reformism and mass mobilization. Regardless of its strategies, the regime's commitment to mediating conflicts over women's labor rights drew government officials into intimate domestic conflicts. Every discussion about women's paid labor implied a larger question about reconciling the postrevolutionary "new woman" with the expectations of women's unpaid domestic labor.

Women's growing participation in the labor force sparked heated public debate over their rights as wage earners, leading to several reforms of the Civil Code and federal labor laws in the 1930s. The prize-winning essay in a contest sponsored by the Federal District government considered married women's rights to retain their wages. ${ }^{5}$ Reformist organizations expressed particular concern about sweated labor in foreign-owned workshops. ${ }^{6}$ Without question, many Mexicans - men and women alike - supported the idea of a male family wage and lamented women's flagging domestic femininity.

Women's labor, whether wage labor in garment workshops or unpaid labor in the home, anchored debates over gendered identities. Postrevolutionary leaders advanced an image of a "new Mexican woman," more modern (read: less pious) in her habits and beliefs, yet no less feminine for her extra-domestic activities. The ruling party's (Partido Nacional Revolucionario, PNR) official newspaper ran a column about women's roles shifting from "factors of consumption" to "factors of production."7 "This entrance of woman into the field of factory production changes, of course, her psychological character," the columnist explained:

It modifies her and gives her a distinct profile that differentiates her radically from the woman we know as domestic ... It should not be thought that this poses an imminent threat to women's femininity. ... [T] he productive woman of our social moment acquires a greater beauty. It makes her, as we can affirm, more feminine.

Divisions did not run cleanly along progressive-conservative lines. Catholic organizations insisted on a traditional, domestic role for women and concentrated on ways to keep women at home, but labor unions also expressed concern about women's presence in factory jobs, citing high unemployment rates among men and downward pressures on wages. ${ }^{8}$

In late July 1934, one of the PNR's affiliated parties wrote to president-elect Lázaro Cárdenas asking him to block women from public employment, arguing that they deprived men of jobs needed to support families. ${ }^{9}$ This argument encountered a mixed reception and was vocally rejected by officials of the Cárdenas regime. The following year's industrial census showed that fully twenty per- 
cent of Mexican households were female-headed, a fact that made national headlines and reshaped the debate over women's labor. A second request followed, and the petitions spurred coverage and editorial commentary in the major Mexico City dailies. The controversy persisted for over a year before finally being put to rest with the administration's clear refusal to dismiss its female employees.

Nonetheless, the discussion about women's participation in the labor force participation retained the rhetoric of "deserving" versus "undeserving" women. The PNR State Women's Committee in Monterrey wrote to Cárdenas soon after his presidential inauguration about its plan to establish a mechanism for directing employers to these more "truly deserving" women rather than to the jóvenes bien [rich kids] who worked only to buy "flashy cars" and "expensive outfits." 10 The "truly deserving" women included only those who lived in a household with no male breadwinner or where the male breadwinner's wage could not meet expenses. For the committee's members, the plan had the additional benefit of forming a clientelistic link with a reliable and dependent pool of domestic workers.

Politicians and public intellectuals expressed endless disagreements about women's right to work while male unemployment remained high, about the effects on the domestic realm of women's participation in the labor force, and about women's safety while working outside the home. Mexico City newspapers ran regular stories about young, working-class women involved in violent, often fatal altercations with jilted lovers or unrequited admirers. The stories almost invariably involved the young women abandoning the sanctity of the home for work or leisure. Often including morbid pictures of the victims, these daily tales instructed young women that the world outside the home remained a dangerous place that they explored at their own peril. ${ }^{11}$

Yet women activists insisted on women's rights in the streets, union halls, and congressional chambers. Communist Party militants and the increasingly well-organized suffrage movement claimed a place for women in the postrevolutionary state-building project. ${ }^{12}$ Although communists and suffragists remained antagonistic toward one another through the early 1930s, the 1935 advent of the Mexican Communist Party's (PCM) Popular Front campaign united them into a mobilized organization campaigning for political, social, and economic rights. ${ }^{13}$ As one woman editorialized in the ruling party's official newspaper,

As long as women's right to think and to work is not recognized within the family, it is useless to grant her the vote, which she cannot exercise freely and cannot consider seriously. She would see the impossibility of attending political meetings that end too late, given that within the criteria of our neighborhoods, an honest señorita cannot allow herself evening excursions of any sort. ${ }^{14}$

Such sentiments underscored the futility of parsing women's public and private roles, including paid and unpaid labor. 
Given women's widespread support for the Catholic Church and prevailing concerns about circumscribing church influence, officials sought ways to instill "revolutionary" values in women through work. Revealing the hegemony of contemporary materialist ideologies, both Catholic organizations and rulingparty leaders expressed the idea that women's participation in the labor force would transform their political consciousness - a consequence the church sought to avoid and the PNR to facilitate. During a campaign speech, Cárdenas exposed the resulting tensions within the regime's vision of the "new woman." "Women must organize," he urged:

Home for them must cease to be a prison. They must become a factor in the production of wealth. They must improve the standard of domestic economies and must, in short, be man's companion in every aspect of his existence. We must not destroy the home but improve it. Let mothers be capable of contributing productive effort but without destroying her children's upbringing; they must go to the workshop, to the field, but in such a way that, due to the modernization of working systems, the home shall not lose any of its cleanliness, warmth, or attractiveness. ${ }^{15}$

In the Cardenista imagination, the "new woman" would enter the wage labor force but without jeopardizing domestic stability or challenging patriarchal privilege. The postrevolutionary Mexican woman would be a hybrid of traditional and modern gender ideals. Although untethered from Catholic "superstition," the "new woman" would retain the abnegation and modesty that purportedly distinguished truly Mexican femininity from European and North American flapperismo.

Cárdenas' speech underscored an important_-and from the regime's point of view, desirable — shift underway within Mexico's labor culture. Stating that women must "become a factor in the production of wealth," Cárdenas sharpened the distinction between the informal economy and formal, wage-based production that exploited technological advances and "modernized" production systems. Work performed in a less-structured fashion did not, in Cárdenas' vision, contribute to the "production of wealth." Modern, wage-earning women would join unions and interact regularly with government or ruling-party officials, extricating them from influences of both the clergy and the clientelism of local, informal politics.

Furthermore, government agencies embraced the opportunity to inculcate "revolutionary values" in working-class and peasant women. Educators and government functionaries viewed the latter group as particularly susceptible to reactionary influences, but they also endeavored to engender class-consciousness in urban working women. Federal education programs for working-class women made this ideological project transparent. In the Secretariat of Public Education's garment-making school in Mexico City, exams emphasized revolutionary labor principles, testing students' understanding of the surplus value theory of labor, the difference between a work stoppage and a strike, and the con- 
tradiction inherent in the bourgeoisie. Short-answer questions asked students to explain how working women contributed to the elimination of social miseries, why it was false that homes are destroyed when women work, and why all working women should join unions. ${ }^{16}$

\section{Gender and Labor in Textile and Garment Production}

Labor unions played a central role in postrevolutionary modernization schemes, and the textile workers' unions, among the most militant and organized before the revolution, became a key target of efforts to shore up a mass base for the new regime. The textile industry implemented the first contrato-ley (contractlaw), which allowed government officials to arbitrate all labor conflicts, a practice that would become a model for other industries. ${ }^{17}$ Thus, the textile industry offered a paradigm for postrevolutionary labor and development policies.

The importance of the cotton textile and garment industries stemmed largely from nationalist economic considerations, since this pair of industries historically had offered other countries a path to modern, industrialized development. The postrevolutionary regime's commitment to nationalist industrialization emerged from two related concerns that had gained prominence during the 1910-1917 revolution. First, the revolution spurred a drive to transform Mexico into a socially, economically, and politically modern nation. Second, it galvanized a nationalist economic spirit, privileging domestic capital over foreign capital, which revolutionary leaders branded a sinister force behind the prerevolutionary Porfirian dictatorship (1876-1910).

The cotton textile industry held a prominent place in the Mexican economy as the country's largest non-extractive industry, and its backward and forward linkages (into domestic cotton cultivation and garment manufacture) made it the country's most important vertically integrated industry. ${ }^{18}$ Government-commissioned studies examined the feasibility of domestically producing the mechanized looms and other heavy machinery rather than importing them. ${ }^{19}$ Contemporary economist Eduardo Villaseñor underscored the importance of maintaining high domestic demand for cotton textiles to promote modernized production processes within the textile industry. ${ }^{20}$ The dramatic October 1936 collectivization of northern cotton production highlighted the integrated industries of cotton cultivation, textile production, and garment manufacture as showpieces for postrevolutionary developmental policies. ${ }^{21}$

The government balanced promoting industrialization with the reality of the uneven Mexican firms' capitalization and the need to protect nationally financed enterprises. During the Depression, the manufacturing sector struggled to compete with the more profitable, capital-intensive petroleum and mining industries for the shrinking pool of direct private investment. ${ }^{22}$ Even in the heyday of Cardenismo, mining and petroleum ventures enjoyed ten times more public investment through the official credit institution than did the textile and garment industries. ${ }^{23}$

Within the project of jump-starting the national economy through protec- 
tionism, the federal government examined the use of foreign material and labor inputs into Mexican production. ${ }^{24}$ In 1930, Mexico's finance ministry undertook its first industrial census, repeating the process at five-year intervals. Inconsistent in their methodology, these censuses provide unreliable longitudinal data on industrial practices, but they offer considerable information amount about policy concerns. ${ }^{25}$ The ministry tracked foreign capital and personnel inputs, assessed levels of mechanization across industries and regions, and tallied numbers of workers by sex, age, and salary levels.

Given the extractive industries' heavy capital demands, the textile industry experienced isolated and limited industrialization in the 1930s. A 1942 government study showed that three-quarters of the looms and between eighty and eighty-five percent of other machinery had been purchased between 1898 and 1910. ${ }^{26}$ As larger firms switched to modern machinery, less capitalized concerns relied on labor-intensive production processes, pushing down wages to remain competitive with more modern production strategies. Economist Donald Keesing described this process as two-stage industrial development, with an initial phase depending heavily on inexpensive labor inputs giving way to a period of stronger growth resulting from higher levels of industrialization. ${ }^{27}$ As wellorganized, militant textile unions refused to accommodate this downward pressure on wages, industrialists promoted a higher universal minimum wage to bring other producers up to the same wage scale that they paid. ${ }^{28}$

Many smaller producers sidestepped these wage demands by employing women at lower pay. Examining the role of women's labor in the textile and garment industries reveals the crucial and generally ignored role that the female workforce played in enabling Mexico's transition to industrial development. Both industries historically had employed significant numbers of women, but the more rapid mechanization of the textile industry shifted it to a predominantly male labor force as it became increasingly mechanized. ${ }^{29}$ Thus, working-class women moved out of higher paying, unionized sectors such as textiles and accounted for a growing percentage of the lower-paying, largely nonunion garment sector. Although the textile and garment industries developed as separate enterprises, they warrant consideration together here because of their integration, the insights gained by comparison, and their particular importance to women's labor conditions.

With the tightening male labor supply during the revolution, women performed more work in the mills, particularly those with the most antiquated machinery, but their numbers declined with mechanization. For example, one government study estimated that women comprised ninety percent of Jalisco's textile labor force in $1918 .{ }^{30}$ By 1928 , the percentage of women cotton textile workers in Jalisco had fallen to fifty-three percent of Jalisco's 2,242 cotton textile workers. Despite this decline, women's presence in the Jalisco cotton textile work force remained higher than in the more industrialized and capitalized state of Puebla, where women comprised less than four percent of cotton textile 9,600 workers. The 1930 industrial census estimated that Puebla had more than five times Jalisco's levels of mechanization and investment and twenty percent high- 
er average wages. ${ }^{31}$ By 1940, while still predominating in less mechanized sectors such as rolling and dying (forming seventy percent of the workforce), women performed only fifteen percent of factory work across the industry and comprised less than ten percent of the workers tending the more mechanized cotton looms. ${ }^{32}$

Several factors contributed to this trend of women's declining presence in factory labor. The Federal Labor Law 1931 and elaborated in 1934 prohibited women's employment on the second and third shifts, night shifts that allowed factories to optimize the use of industrial machinery and that by contract paid higher wages than the day shift. The laws also imposed stiff requirements for maternity leave and childcare provision and restrictions on women's operation of heavy machinery.

Most importantly, union leaders gained control over hiring into the most coveted apprenticeship positions to train for high-paying industrial jobs. These positions were given almost exclusively to men, often to the sons of current employees. The 1939 contrato-ley stipulated that "the contracting unions will provide apprentices, in every case preferring the sons [hijos] of the workers in the same factory, and especially those whose fathers [padres] practice the craft or a trade that is to be taught." 33 This provision, which became common in industrial unions, preserved a vestige of the pre-industrial, family-based labor structure associated with artisanal production, effectively recreating a kind of primogeniture of industrial labor. In other words, as the textile industry slouched toward higher levels of industrialization, textile production became associated with skilled, masculine, higher paying labor, relegating women to jobs viewed as unskilled, feminine, and unsuited to a family wage. ${ }^{34}$ Many displaced working women sought refuge in the garment industry, where tasks such as sewing, finishing, and embroidery were labeled unskilled.

The relationship between wages and mechanization fostered tensions among employers as well. Most textile and garment producers did not enjoy the technological advances that would allow them to compete with more heavily capitalized and industrialized firms. This uneven modernization in production systems also frustrated more mechanized producers, since they often faced product irregularities or production bottlenecks, thus limiting the efficiency and productivity of the more mechanized plants.

Furthermore, the largest, most heavily industrialized companies faced unions strong enough to demand higher wages and greater job security. While many employers tried to circumscribe union control through intimidation and bribery of union officials, others developed an allegiance to the enforcement of the industrial rule of law. Employers who risked antagonizing their unions if they committed labor law violations protested the conspicuous divide between labor law and common business practices. Concerned about smaller firms that, unconstrained by vigilant labor unions, paid workers below minimum wage and avoided collective contracts, larger employers called on the federal government to enforce labor laws and a higher minimum-wage standard. ${ }^{35}$ While Labor Department officials recognized the social dislocations and economic instability 
that would inevitably follow strict enforcement of the 1931 Federal Labor Law, they also understood that the rule of law comprised an essential component of modern, industrial development.

During this take-off period of the "Mexican Miracle," the female labor force provided an indispensable buffer for less mechanized producers. By defining certain jobs as lower paying women's work and by employing women as subminimum-wage apprentices, small, labor-intensive producers stayed afloat and still endorsed the industrial family wage. As economic historian Stephen Haber argued, the 1930s recovery and growth of the cotton textile industry relied almost entirely on recent immigrants' low-capital enterprises. ${ }^{36}$ For these laborintensive endeavors, women provided a low-paid, flexible work force.

\section{The First and Second Investigative Committee Reports}

Amid growing concerns about women's role in the unevenly industrializing work force, the Investigative Committee of the Situation of Women and Children Workers set out in 1936 to research the conditions of women garment workers. In choosing to investigate the garment industry, the inspectors endeavored to root out the worst cases of "anti-economic" behavior. They expressed particular concern about clandestine workshops, piecework wages, and, most especially, outwork: practices that allowed employers to elude state observation and, critics argued, undermined the process of modernization. Within a modern industrial framework, as suggested by Cárdenas' campaign statement about women's labor, domestic spheres and productive spheres should be distinctly separate. Thus, outwork practices precipitated concerns that unhealthy labor conditions spilled over from the workshop into the home, exacerbating exploitative labor practices by drawing other family members into production. ${ }^{37}$

The committee focused on smaller enterprises. Although the study included several larger concerns boasting nearly one hundred women employees, the average workshop employed only fourteen workers. Surveying 2,835 workers in 208 workshops and small factories, the inspectors found that nearly thirteen percent of fixed-salary employees and more than fifty-one percent of piecework employees earned less than the legal minimum wage. Despite the mandates of federal labor laws, the workers received no paid vacation or, in some cases, no vacation at all, rarely enjoyed union protections, and often remained classified as apprentices or probationary workers despite having worked many years for the same employer. ${ }^{38}$ Piecework rates were abysmally low, particularly for those women who performed outwork.

Workplace health concerns assumed a central position in the committee's report. The committee's head, Federico Ortiz, had dedicated his career to public health after graduating at the top of his medical-school class in $1925 .{ }^{39}$ The investigative committee sought out egregious health violations and labor abuses, reporting high levels of tuberculosis, dirty and dusty conditions, the absence of ventilation, and inadequate bathroom facilities. The report also detailed blatant labor law violations. One inspector found that a woman had worked as an 
"apprentice" for twenty years, and many workshops exceeded the statutory limit of five percent on apprentices or probationary workers. Nearly seventy percent of the women surveyed performed piecework, but almost none of them received the daily minimum wage of two pesos. Even fixed-wage workers only averaged $\$ 1.50$ per day, still well short of the federally mandated minimum.

The report revealed that low levels of mechanization exacerbated poor labor conditions. Nearly a quarter of the garment workers surveyed performed their work by hand, and nearly a fifth of the workers used machines but labored standing up, an imposition considered particularly inappropriate for women. Women lost wages when machinery broke down or their employers could not afford necessary inputs, such as cloth, thread, or electricity. Some pieceworkers even paid for many supplies and machinery out of their meager incomes.

The inspectors repeatedly related instances of employer intimidation, threatening workers' jobs and preventing them from talking to inspectors. As one report explained, "The workers recognize that [the payment system] is unjust, but knowing the threat that hangs over them of losing their jobs if they denounce the situation, they prefer to subject themselves to its demands, keeping silent and denying all facts." 40 Indeed, several reports indicated that an unusually courageous worker or surreptitious neighbor had passed along information about the workshops' labor conditions.

Throughout the report, the inspectors spoke for the workers rather than relating workers' responses. Whereas the report cited extensive portions of labor contracts and letters from employers' organizations, the many interviews with workers appeared only through the inspectors' speculations about the workers' intended meanings. In other words, having questioned nearly three thousand garment workers about their labor conditions, the inspectors included no direct testimony from the workers themselves. The report's overarching message emphasized the need for government officials to speak on the workers' behalf and to redeem this hopelessly backward and exploitative industry.

The report attributed poor conditions largely to organized labor's near absence in the garment industry. Pointing out that nearly ninety percent of the industry-presumably excluding those workshops that operated clandestinely-had no union representation at all, the report concluded that government officials must defend workers" interests. "Is it strange, with this situation, that those poor women are victims of merciless exploitation?" queried the report.

It must be emphasized that this [the low levels of unionization] explains the Department [of Labor]'s decided intervention in favor of this sector of the national proletariat, surely the weakest, the most exploited, and, therefore, the most urgently requiring help from the Government of the Revolution. ${ }^{41}$

In this respect, the inspectors acted more as labor organizers than data collectors. Inspectors proudly recounted instances when they openly challenged employers about labor practices and exhorted workers to seek the protection of the government and of labor unions. Margarita Jiménez, one of the most prolific in- 
spectors, included a disparaging account of the coat-making workshop "Almacenes Cataluña," describing her confrontations with the forewoman and the owners. "In light of all this," she concluded, "the workers wanted to organize themselves, but only so long as they enjoyed the support of the Department of Labor, given its concern with improving the workers' situation." 42

However, the inspectors also exhibited some sympathy with these smallscale employers. Ana María Hernández, an inspector and PNR activist, spearheaded efforts to federalize garment-industry labor relations as they had been under the textile industry's 1931 contrato-ley. ${ }^{43}$ She promoted two employers' associations that lobbied to uphold federal labor laws. This effort at unification and social peace through government arbitration closely followed the cotton textile industry's model. As in the textile industry, a contingent of garment manufacturers sought punishment for employers who operated clandestinely and paid illegal wages. Meanwhile, they highlighted their own compliance with federal labor laws to avert stricter enforcement or more stringent legislation. The organizations Hernández supported sought "to regularize and generalize among all their members the wage rates in strict compliance with the law and to cooperate in the creation of federally mandated collective contract and wage scale, resulting from a worker-employer convention." 44

These appeals revealed the precarious situation of many small employers. Most workshop owners were themselves not far removed from wage earning. One employers' association, established in January 1936, wrote an addendum to the investigative committee's report, calling for national standards for the garment industry. It explained:

This industry consists of a great number of small industrialists that employ primarily female workers and a very small percentage of men. The vast majority of these needlework workshops have developed in a very stunted manner, which could almost be described as miserable, due to their disorganization and the scarce resources that they individually control, resulting in a ruinous competition among them. Unable to secure sustenance and progress through price stabilization, these industrialists have obtained their subsistence through lower costs, obligating them to pay workers extremely low salaries, nearly starvation wages. Because the workers are mostly women, they have been able to content themselves with this miserable compensation. ${ }^{45}$

The association went on to object that the labor authorities' failure to enforce minimum wage laws had forced many of its members to leave the organization or ignore its regulations. Even before the January 1936 minimum-wage increase from $\$ 1.50$ to $\$ 2.00$ per diem, association members struggled to compete with clandestine producers paying workers only fifty to seventy-five centavos per day. Without adequate law enforcement, the organization maintained, increasing minimum-wage rates forced more producers to operate illegally to stay afloat.

The Department of Labor maintained that state employer-worker cooperation would result in higher wages based on the association's recommenda- 
TABLE 1.

\begin{tabular}{lcccccc}
\hline Item & $\begin{array}{c}\text { Outwork } \\
\text { Production }\end{array}$ & $\begin{array}{c}\text { Outwork } \\
\text { Wage }\end{array}$ & $\begin{array}{c}\text { Workshop } \\
\text { Production }\end{array}$ & $\begin{array}{c}\text { Nonunion } \\
\text { Wage }\end{array}$ & $\begin{array}{c}\text { Union } \\
\text { Wage }\end{array}$ & $\begin{array}{c}\text { Association } \\
\text { Wage }\end{array}$ \\
\hline Suit & 5 & $16.66 \phi$ & 6 & $20.83 \phi$ & $41.25 \phi$ & $50.00 \phi$ \\
Pants & 12 & $6.25 \phi$ & 18 & $8.33 \phi$ & $10.41 \phi$ & $12.00 \phi$ \\
Blouse & 10 & $10.41 \phi$ & 12 & $12.50 \phi$ & $14.58 \phi$ & $18.00 \phi$ \\
Trousers & 5 & $14.58 \phi$ & 7 & $18.75 \phi$ & $20.83 \phi$ & $30.00 \phi$
\end{tabular}

tions. Using standards provided by one of the manufacturers' associations, the inspectors' report offered a comparison of daily production averages and piecework wages among outworkers, nonunionized workshops, unionized workshops, and association workshops (see Table 1). ${ }^{46}$ The striking differences in potential daily wages are deceptive, however. Association rates remained theoretical recommendations made to member-employers who complied only within the constraints of profitability. As the employers' appeal underscores, such standards often remained no more than idealistic imaginings as thousands of small garment workshops competed to supply the large clothing houses. The report indicated that workers and employers alike advocated state arbitration of their differences. Without state intervention, "wage anarchy" would prevail and destabilize the entire productive system. ${ }^{47}$ Thus, the Department of Labor intertwined labor rights and industrial development in a paternalist but progressive agenda.

Two years later the Labor Department published a second report on the conditions of working women and children. ${ }^{48}$ The differences between the two documents are obvious even before opening them. The 1936 report offered a substantive, lengthy account with typeset print and several appendices of data, while the 1938 report filled only twenty pages and apparently was produced on a standard typewriter. The cover of the 1936 report featured the socialist-realist style sans serif typescript and an engraving of women marching in the streets carrying banners proclaiming their support for federal labor laws. By contrast, the 1938 report cover featured a more traditional typescript and a photograph of three smiling women posing with the tools of their trades. The disparity between the two reports becomes even more apparent upon reading them. The 1936 report included a detailed account of the committee's methodology, the names of the committee members, excerpts from their inspection reports, sample questionnaires, charts of data collected, and examples of their correspondence. The 1938 report was simply signed by Isaac Olive, the oficial mayor of the labor department and a career lawyer and politician, and contained no direct information from or about the inspectors.

Similarly, the 1938 report's recommendations differed significantly from those of its predecessor. Whereas the 1936 committee had asserted the impor- 
tance of women workers earning higher wages and enjoying better working conditions, the 1938 report stressed the need for a family wage and insurance for male workers. Striking a very different tone from the demands for respect for women workers that had permeated the 1936 report, the latter document explained that:

When the worker cannot create a savings fund, due to his poor wages and the high cost of living, he faces the painful situation that, upon his death, his family and especially the women who depend upon him are forced into misery and perhaps prostitution. This constitutes a grave moral threat that causes dejection in the worker, having repercussions for his productive capacity, which will be less intense, to the detriment of the firms. ${ }^{49}$

This shift in tone from fulfilling the commitments of the revolutionary struggle to a moralizing paternalism about the need for greater frugality and foresight among workers follows the shift in Mexican political climate more generally during the second half of the Cárdenas presidency. As the regime sought to consolidate its gains following the reorganization of the ruling party and the expropriation of the petroleum industry, it turned toward more conciliatory, conservative labor and social policies. Rather than focusing on the exploited women of the garment industry, the 1938 investigative committee turned to the concerns of the "so-called 'middle class' ... who have generally remained apart from the Governments of the Revolution, as a result of various religious or political prejudices." 50 The concerns of the committee, like those of Cardenismo, had changed from mobilizing mass organizations of peasants and workers to appeasing the middle class and drawing it into the ranks of regime supporters.

\section{Battling the Right}

The Cardenistas' rightward shift resulted from mounting concerns within both the ruling party and the Communist Party about domestic fascism, particularly the growing strength of the fascist Gold Shirts and the quasi-fascist Sinarquistas. In mid-1937, Communists adopted the "Unity at Any Cost" policy, ensuring the Cárdenas government that it would not face any substantial challenges from the organized left and could concentrate instead on fighting battles on the right. The Labor Department's leadership changed completely in 1937 when Genaro Vázquez, who had ordered the 1936 investigative report, became Mexico's attorney general. ${ }^{51}$ This changing of the guard created the opportunity for an ideological shift in the department, as Cardenista officials demonstrated mounting intolerance for strikes and labor mobilizations.

Furthermore, the highly mobilized women's movement seemed on the brink of achieving its long-pursued goal of women's suffrage. Postrevolutionary political leaders often questioned the advisability of women's suffrage, assuming women's support for the regime's Catholic and conservative opponents. Suffragists, therefore, took pains to show that they would not upset the careful po- 
litical balance in any way that might favor conservative challengers. As Congress deliberated over a constitutional amendment to grant women voting rights, feminist organizers bent over backwards to demonstrate their allegiance to the postrevolutionary regime and prove their credentials as citizens. ${ }^{52}$ Since PCM militants also organized the Popular Front-inspired women's confederation, the combination of "Unity at Any Cost" and the precarious status of the suffrage amendment left women activists reluctant to challenge the Labor Department's conservative turn on women's labor rights.

With the containment of left and feminist opposition, Cardenistas concentrated their energies on appealing to women attracted to the fascist and Catholic organizations. As part of the regime's overriding goals of political stability and modernization, Cardenista labor officials attempted to co-opt the family-wage agenda of conservative groups such as the Mexican Catholic Women's Union (UFCM), a branch of Mexico's Catholic Action. In 1938, the UFCM organized a congress to consider strategies to attract working women into its ranks. ${ }^{53}$ Working outside the home, the UFCM leadership insisted, led women to "religious indifference" and the abdication of domestic duties. Catholic Action, they maintained, should rescue working-class women from the "moral repercussions" of union membership. They pointed to the example of the Depressionplagued United States and asserted that the "invasion of women into the workshops and factories" explained the rising tide of unemployment.

Organizations such as the UFCM continued the Catholic Church's longstanding efforts to reach out to popular groups. When the state failed to fulfill its promises of social justice, the Catholic Church, with its long tradition of assisting the most indigent, stepped into the breach and made its own claims for justice, putting the Cárdenas administration once again on the defensive. ${ }^{54}$ And Catholic Action's insistence on linking female employment and low wages for men appealed to many working-class men and women who favored a family wage that would allow working-class women to concentrate their energies in their homes.

To Cardenista officials seeking to diminish the appeal of organizations such as Catholic Action, supporting the family-wage campaign made sense. It reinforced modernist efforts to separate public and private realms as well as wage and non-wage labor. It appealed to working-class men and women as well as to middle-class reformers. Finally, it countered the accusations that the regime sought to abolish gendered identities by drawing women into the masculinized world of labor unions and politics while emasculating men through unemployment and underemployment. The Labor Department, deflecting accusations of communist influence, could better defend itself against conservative criticisms by obscuring rather than challenging women's labor conditions.

\section{Conclusions}

The investigative reports of 1936 and 1938 raise as many questions as they answer. They do not assess, for example, the effect of truly equalizing male and fe- 
male wages, as the federal labor laws stipulated. Nor do they measure the Labor Department's success in enforcing labor laws. Neither report indicates who brokered female labor, particularly in the decentered garment industry, where many women performed piecework or outwork. The social linkages of these workplaces, therefore, remain invisible, save for a few offhand references to neighbors. Furthermore, the reports' determination to portray women workers as blameless victims obscured workers' own efforts at resistance. Indeed, the lack of cooperation by some of the garment workers may have resulted as much from suspicion of state authorities as they did from fear of employer retribution.

The relationship among gender, state-formation, and industrialization developed in a complex matrix of perceptions and interest groups. The Cardenista regime struggled to balance the need for economic development with its commitments to revolutionary ideals and political stability. The cotton textile and garment industries appeared to offer an ideal setting for nationalist economic policies, given not only their prominence in the economy but also their use of domestic inputs and domestic markets. However, closer inspection reveals that during this crucial period of industrial transformation leading up to the "Mexican Miracle," the female work force played a critical role in evening out the competition among labor-intensive and capital-intensive enterprises. The progressive, if reformist, 1936 investigative committee saw in this situation a perfect opportunity for the state to step in and mediate. Despite his aspirations, Cárdenas was not a benevolent dictator who could intervene and choreograph social change at will. The recommendations of the labor department, limited as they were, foundered on the constraints of a patriarchal society, uneven economic development, and growing threats from conservative opposition movements.

\section{NOTES}

I would like to thank Michael F. Jiménez, Miguel Centeno, Susan Gauss, Mark Lawrence, and the anonymous reviewers for $I L W C H$ for their exceedingly helpful feedback. Also, David Montgomery offered insights into comparisons with United States textile and garment workers.

1. Departamento del Trabajo, Informe sobre las labores de la Comisión Investigadora de la Mujer y los Menores Trabajadores (Mexico, 1936). (Hereafter, Informe, 1936. All translations are my own.

2. Nearly twenty-seven percent of garment workers had a sixth-grade education. The 1930 population census pegged literacy of women over ten years old at seventy percent, considerably lower than the ninety-three percent literacy rate found among garment workers. See Dirección General de Estadística, Quinto censo general de población de 1930 (Mexico, 1934), 225.

3. Lázaro Cárdenas, Ideario político, ed. Leonel Durán (Mexico, 1972), 189-191.

4. Lázaro Cárdenas, Palabras y documentos, Vol. 1 (Mexico, 1978), 202.

5. El Nacional, 12 November 1929, 8 .

6. El Nacional, 6 May 1931, 8.

7. El Nacional, 15 October 1932, 8. In 1938, the PNR restructured to become the Partido de la Revolución Mexicana (PRM), which in turn became the Partido Revolucionario Institucional (PRI) that governed Mexico until 2000.

8. Dawn Keremitsis, "Latin American Women Workers in Transition: Sexual Division of the Labor Force in Mexico and Colombia in the Textile Industry," The Americas, 15, 4 (April 1984).

9. See El Universal, 1, 2, 6, and 10 August 1934, 22 October 1935; La Prensa, 2, 6, 14, and 22 August 1934, 16, 17, 24 October 1935; Excélsior, 2 August 1934, 28 September 1935, 17 and 
23 October 1935; El Nacional, 5, 6, 12, 13, and 22 August 1934, 4 October 1935; El Día, 16 October 1935 .

10. Comité Estatal del Partido Femenista Revolucionario (PNR) to Cárdenas, 27 December 1934, AGN, RP, LCR, exp. 437.1/29.

11. Anne Rubenstein also discussed this phenomenon in Bad Language, Naked Ladies, and Other Threats to the Nation: A Political History of Comic Books in Mexico (Durham, 1998).

12. For PCM's the growing interest in attracting women to its ranks, see El Machete during this period; Departamento Femenil del Partido Comunista, “ $i A$ las Obreras, Campesinas y Mujeres Indigenas en General!” 1 October 1931, and Laura Durán, “A las soldaderas, A las técnicas, A las mujeres de los policías!" both found in Rodolfo Echeverría Martínez Collection, Box 16, Folder 7, Hoover Institution Archives, Stanford University. For accounts women's activism, see Anna Macías, Against All Odds: The Feminist Movement in Mexico to 1940 (Westport, CT, 1982); Shirlene Ann Soto, Emergence of the Modern Mexican Woman: Her Participation in the Revolution and Struggle for Equality, 1910-1940 (Denver, 1990); and Carmen Ramos Escandón, "Women and Power in Mexico: The Forgotten Heritage, 1880-1954," in Women's Participation in Mexican Political Life, ed. Victoria E. Rodríguez (Boulder, 1998), 87102.

13. Jocelyn Olcott, "Las Hijas de La Malinche: Women's Organizing and State Formation in Postrevolutionary Mexico, 1934-1940" (Ph.D. diss., Yale University, 2000) and Esperanza Tuñón Pablos, Mujeres que se organizan: El Frente Unico Pro Derechos de la Mujer, 1935-1938 (Mexico, 1992).

14. El Nacional, 5 August 1933, 8.

15. Secretaría de Prensa y Propaganda del Partido Nacional Revolucionaria, La gira del General Lázaro Cárdenas: sintesis ideológica (Mexico, 1934), 136-137.

16. From 1936 report of the Escuela de Costura y Confección, Archivo Histórico de la Secretaría de Educación Pública (AHSEP), Serie Instituto de Orientación Socialista, caja 3961/ 3100/12, exp. 5 .

17. Jeffrey Bortz, "The Genesis of the Mexican Labor Relations System: Federal Labor Policy and the Textile Industry, 1925-1940," The Americas 52 (1995): 43-69.

18. Stephen Haber, Industry and Underdevelopment: The Industrialization of Mexico, 1890-1940 (Stanford, 1989). In 1930, the textile and garment industries ranked second and fourth, respectively, in personnel employed. See Dirección General de Estadística, Primer censo industrial de 1930 (Mexico, 1934), 32. By 1940, the cotton textile industry ranked second after mining in personnel employed and total salaries paid and second after metalworking plants in the values of primary materials consumed and of production. In these categories, various sectors of the garment-making industry ranked between twenty-sixth and thirtieth, while others ranked far lower. See Dirección General de Estadística, Tercer censo industrial de 1940 (Mexico, 1944), 41-51.

19. Jesús Díaz Barriga, "Proyecto de plan de industrialización del país y financiamiento," 24 October 1938, Archivo General de la Nación (AGN), Ramo Presidentes (RP), Grupo Lázaro Cárdenas del Río (LCR), file 545.3/295.

20. Eduardo Villaseñor, Nuestra industria textil del algodón (Mexico, 1934), 15.

21. Clarence Senior, Democracy Comes to a Cotton Kingdom: The Story of Mexico's La Laguna (Mexico, 1940); Joe C. Ashby, Organized Labor and the Mexican Revolution under Lázaro Cárdenas (Chapel Hill, 1963); Barry Carr, Marxism and Communism in Twentieth-Century Mexico (Lincoln, 1992).

22. Haber, Industry and Underdevelopment, $150 \mathrm{ff}$. For the disparity foreign investment in these sectors, see "Foreign Investments in Mexico," Mexican Commerce and Industry, December 1931, 6-7.

23. Nacional Financiera, S.A., Statistics on the Mexican Economy (Mexico, 1974), $273-$ 274.

24. The 1930 Hawley-Smoot Tariff raised import duties on nearly sixty percent of all Mexican goods entering the United States. See Hamilton, Limits of State Autonomy, 115 and Haber, Industry and Underdevelopment, 153. Mexico responded in 1931 with a nationalist economic campaign. Like many consumption-oriented programs, the public rhetoric surrounding the nationalist campaign targeted women, who were seen as the primary consumers. Industrialists continued to import big-ticket items, such as heavy machinery, that had the greatest economic impact.

25. Early industrial censuses surveyed firms rather than people, excluding employers that 
stayed below the radar of census-takers. Women, who form a larger percentage of the informal economy, are likely underrepresented by this data.

26. Cited in Sanford A. Mosk, Industrial Revolution in Mexico (Berkeley, 1950), 126.

27. Donald B. Keesing, "Structural Change Early in Development: Mexico's Changing Industrial and Occupational Structure from 1895 to 1950," Journal of Economic History 29 (1969): 716-738.

28. See Bortz, "Genesis"; Jesús Rivero Quijano, "La industria textil de algodón y el maquinismo," n.d. [1931].

29. Women's role in textile production has received scant scholarly attention for the colonial and early national periods and even less for the postrevolutionary period. See, for example, Dawn Keremitsis, La industria textil mexicana en el siglo XIX (Mexico, 1973) as well as her article "Latin American Women Workers in Transition: Sexual Division of the Labor Force in Mexico and Colombia in the Textile Industry," The Americas 40 (1984): 491-504. The garment industry has attracted more notice, particularly since the 1985 Mexico City earthquake sparked international concern about the women's working conditions in the city's garment district. Many studies of women in the textile and garment sectors are regional or factory studies. See, for example, Fiona Wilson, De la casa al taller (Morelia, 1990) and Estela Leñero, El huso y el sexo: la mujer obrera en dos industrias de tlaxcala (Mexico, 1984); María Teresa Fernández Aceves, "Class, Gender and Power in Guadalajara: Political Mobilization of Schoolteachers, Textile Workers, and Tortilla Makers, 1920-1940" (Ph.D. diss., University of Illinois, Chicago, 2000). On women textile workers during the Porfiriato, see Verena Radkau, "La Fama" y la vida: una fábrica y sus obreras (Mexico, 1984).

30. Cited in Keremitsis, "Latin American Women Workers," 494.

31. Cited in Ana María Hernández, La mujer mexicana en la industria textil (Mexico, 1940), 118-119; Primer censo industrial de 1930, 13-24.

32. Tercer censo industrial de 1940, 56.

33. "Contrato colectivo de trabajo, obligatorio en la industria textil del algodón y sus mixturas," Revista del Trabajo, August 1939. Although the words hijos and padres can be used in a gender-neutral sense to mean children and parents, in practice, the best textile jobs were passed from father to son.

34. For a discussion about the relationship among gender, labor, and skill definitions, see Ava Baron, ed., Work Engendered: Toward a New History of American Labor (Ithaca, 1991).

35. See Bortz, "The Genesis of the Mexican Labor Relations System."

36. Haber, Industry and Underdevelopment, 171-189.

37. Women's outwork attracted attention not only from labor inspectors but also in the mainstream media. By the 1940s, several university students wrote theses exploring its dangers. See Carlos Cuota Alva, "Trabajo a domicilio" (Thesis, Universidad Nacional Autónoma de México, 1944); and Carlos Yaspik Guerra, "De trabajo a domicilio" (Thesis, Universidad Nacional Autónoma de México, 1944).

38. Inspectors most likely would have found similar abuses of male workers but viewed them as more egregious when committed against women.

39. Roderic Ai Camp, Mexican Political Biographies, 1935-1993 (Austin, 1995), 526.

40. Informe, 1936, 28.

41. Informe, 1936, 15.

42. Informe, $1936,30$.

43. A leading feminist and fellow-traveler of the PCM, Ana María Hernández was a highprofile activist throughout the 1930s and 1940s. In 1940, she drew her work on as a labor inspector to write the muckraking book, La mujer mexicana en la industria textil.

44. Informe, 1936, 48.

45. Informe, 1936, 65.

46. Informe, 1936, Appendix 12. Daily outwork production rates reflected daily averages using a pedal-powered sewing machine; handwork produced fewer items per day. Workshop production averages reflected using electric machines. Wages are in 1936 Mexican centavos.

47. See also Bortz, "Genesis." Certainly after a quarter century of violence and political uncertainty, this description would have resonated with the common experience of many producers.

48. Departamento Autónomo del Trabajo, Informe de las labores realizadas por la Comisión Investigadora de la Situación de la Mujer y de los Menores Trabajadores (Mexico, 1938). Hereafter, Informe, 1938. 
49. Informe, $1938,6-7$.

50. Informe, $1938,8$.

51. Vázquez was replaced by Antonio Villalobos, a ruling-party loyal who would become the president of the party's executive committee during the administration of Cárdenas' more conservative successor Manuel Avila Camacho. Camp, Mexican Political Biographies, 735.

52. Women achieved the right to vote in federal elections in 1953. The 1937 amendment languished in Congress, which refused to publish the results of its vote on the matter, thus negating the apparent victory.

53. Colección Unión Femenina Católica Mexicana, Archivo Histórico, Universidad Iberoamericana, Mexico, D.F., IV Asamblea General de la Unión Femenina Católica Mexicana, 4 October 1938, UFCM, box 4, folder 26.

54. See Nora Hamilton, The Limits of State Autonomy and Alan Knight, "Cardenismo: Juggernaut or Jalopy?" Journal of Latin American Studies 26 (February 1994): 73-107. 